\title{
Inshore migration of the tropical eels Anguilla spp. recruiting to the Poigar River estuary on north Sulawesi Island
}

\author{
Hagi Yulia Sugeha ${ }^{1, *}$, Takaomi Arai ${ }^{1, * *}$, Michael J. Miller ${ }^{1}$, \\ Daniel Limbong ${ }^{2}$, Katsumi Tsukamoto ${ }^{1}$
}

${ }^{1}$ Ocean Research Institute, The University of Tokyo, Minamidai, Nakano Tokyo 164-8639, Japan
${ }^{2}$ Faculty of Fisheries and Marine Science, Sam Ratulangi University, Manado 95115, Indonesia

\begin{abstract}
To understand ecological and behavioral aspects of inshore migration of tropical eels, Anguilla spp., we collected 32836 glass eels in the Poigar River estuary on north Sulawesi Island, Indonesia, in monthly collections from 1997 to 1999. The specimens were identified using morphological characters, and 3 species, A. celebesensis, A. marmorata, and A. bicolor pacifica, were found each year in fluctuating abundances. A. celebesensis was the most abundant species and comprised $73.5,79.5$, and $81.9 \%$ of all glass eels recruiting to the estuary of the Poigar River in 1997, 1998, and 1999, respectively. This species was relatively abundant in all 3 years with peaks during June in 1997 and 1998, and during September in 1999. A. marmorata was the second most abundant species and comprised $23.8,18.8$, and $17.7 \%$ of the yearly catches, respectively, and reached peaks in abundance during June in 1997 and 1998, and during January in 1999. A. bicolor pacifica comprised only 2.7, 1.7, and $0.3 \%$ of the yearly catches, respectively, with peak catches in June in 1997, in January in 1998, and in January and February in 1999. A. celebesensis and A. marmorata were collected almost throughout the year in 1997, 1998, and 1999, suggesting that in contrast to the temperate eels that recruit during half the year from winter to spring, these tropical eel species recruit to some degree throughout the year. Glass eels clearly were more abundant during new moon sampling events, with a total of 3075, 183, 3, and 90 glass eels collected in 10 sampling periods during new moon, waxing moon, full moon, and waning moon, respectively. All glass eels were collected at night (18:00 to 05:00 h) when light intensity ranged from 0 to 1.86 lux, and no glass eels were collected during the day (06:00 to 17:00 h) when light intensity ranged from 500 to 150000 lux. During new moon, more glass eels were collected during flood tide than during ebb tide. These results suggest that a greater number of glass eels recruited to the Poigar River estuary at night, during new moon and during flood tide.
\end{abstract}

KEY WORDS: Glass eels - Tropical eels - Species composition - Seasonal occurrence $\cdot$ Inshore migration $\cdot$ Lunar cycle $\cdot$ Light intensity $\cdot$ Tidal rhythm

\section{INTRODUCTION}

The catadromous eels of the genus Anguilla appear to have originated in the tropical regions of the Pacific

*E-mail: yuli@ ori.u-tokyo.ac.jp

${ }^{* *}$ Present address: Otsuchi Marine Research Center, Ocean Research Institute, The University of Tokyo, 2-106-1, Akahama, Otsuchi, Iwate 028-1102, Japan
Ocean, where the greatest number of species is found (Tsukamoto \& Aoyama 1998). Two thirds of the recognized 18 Anguilla species and subspecies are found in the tropical Pacific, while only 6 are found in temperate regions of both the Pacific and Atlantic Oceans. Seven species and subspecies of tropical eels occur in the western Pacific around Indonesia (Ege 1939, Castle \& Williamson 1974, Arai et al. 1999a). Both morphological and genetic studies indicate that tropical eels are 
more closely related than temperate eels to the ancestral eel (Ege 1939, Castle \& Williamson 1974, Aoyama et al. 1998). Using dentition as a primary character, Ege (1939) distinguished 2 major lines of angullid speciation and 1 of them arose from $A$. ancestralis found on Celebes Island, which was later determined by Castle \& Williamson (1974) to be A. celebesensis. A recent genetic study on the phylogeny of anguillid eels found that $A$. marmorata appeared to be the most ancestral of the 8 species examined (Bastrop et al. 2000). However, in a more recent study Aoyama et al. (2001) analyzed 18 species of anguillid eels, found that $A$. borneensis from Borneo Island was the most basal species, and proposed that anguillid eels originated near presentday Indonesia and dispersed to both the east and west along paleo-circumglobal equatorial currents. Thus, the long-distance catadromous migrations of anguillid eels may have originated in the tropical species, and studying larval migration and early life history of tropical eels may provide a greater understanding of the origins of the catadromous migration of anguillid eels.

Ecological studies on the migration and early life history of anguillid eels have been mainly on temperate eels. The spawning location and season have been described for some species of temperate eels (Schmidt 1922, Tsukamoto 1992), and there have been various studies on the glass eels Anguilla japonica (Matsui 1952, Tzeng 1985, Tsukamoto 1990, Cheng \& Tzeng 1996, Arai et al. 1997), A. anguillla (Deelder 1952, Creutzberg 1958, Gandolfi et al. 1984, Gascuel 1986, Tongiorgi et al. 1986, Lecomte-Finiger 1992, Arai et al. 2000), A. rostrata (Sorensen 1986, Sorensen \& Bianchini 1986, Wippelhauser \& McCleave 1987, Haro \& Krueger 1988, Martin 1995, Wang \& Tzeng 1998, Arai et al. 2000), and A. australis and A. dieffenbachi (Jellyman 1977, 1979, Todd 1981, Sloane 1984, Arai et al. 1999b, Jellyman et al. 1999, Marui et al. 2001). Some of these studies have described the larval duration and growth, timing of metamorphosis and recruitment to coastal waters, or timing of inshore migration of glass eels and elvers in relation to environmental factors such as temperature, salinity, tide cycle, and lunar phase. However, knowledge about the inshore migration of tropical species (Arai et al. 1999a, c, d,e, 2001, Arai 2000) is limited compared with that of temperate anguillid species. Furthermore, in tropical areas, several anguillid eels often occur sympatrically, and the identification of some species is difficult due to intraspecies variation of the morphological characters that overlap considerably between species (Tabeta et al. 1976).
The first study to examine the seasonal species composition of tropical glass eels during recruitment was a 1 -year study of the glass eels recruiting to the Poigar River on north Sulawesi Island, Indonesia, which used genetic and morphological characters to examine the species composition and relative abundance of glass eels throughout the year in 1997 (Arai et al. 1999a). However, this study did not examine morphological characters other than ano-dorsal length as a percentage of total length and did not report variations in catches in relation to the lunar cycle or other environmental factors. The present 3-year study used the catch data from 1997 and additional data from 1998 and 1999 to examine the species composition and seasonal abundance over a longer period of time to provide information on the inter-annual variation in recruitment of tropical anguillid eels. In addition, a wide range of morphological characters of the specimens from all 3 years was measured. Furthermore, the possible effects of environmental factors such as lunar cycle, light intensity, and tidal rhythm on the fluctuations of the abundance of glass eels recruiting to the estuary of the Poigar River on Sulawesi Island were examined.

\section{MATERIALS AND METHODS}

Glass eels were collected at the mouth of the Poigar River, north Sulawesi Island, Indonesia (Fig. 1), from 1997 to 1999 during 4 moon phases (new moon, waxing moon, full moon, waning moon). They were caught in a $10 \mathrm{~m}$ transect along the beach within $1.5 \mathrm{~m}$ from shore using 2 triangular scoop nets (mouth $0.3 \mathrm{~m}^{2}$, $1 \mathrm{~mm}$ mesh). The nets were fished simultaneously at depths of 25 to $50 \mathrm{~cm}$ in 10 replicate passes at hourly intervals for a full day in 1997 and only at night (18:00 to 05:00 h) in 1998 and 1999. Preliminary sampling

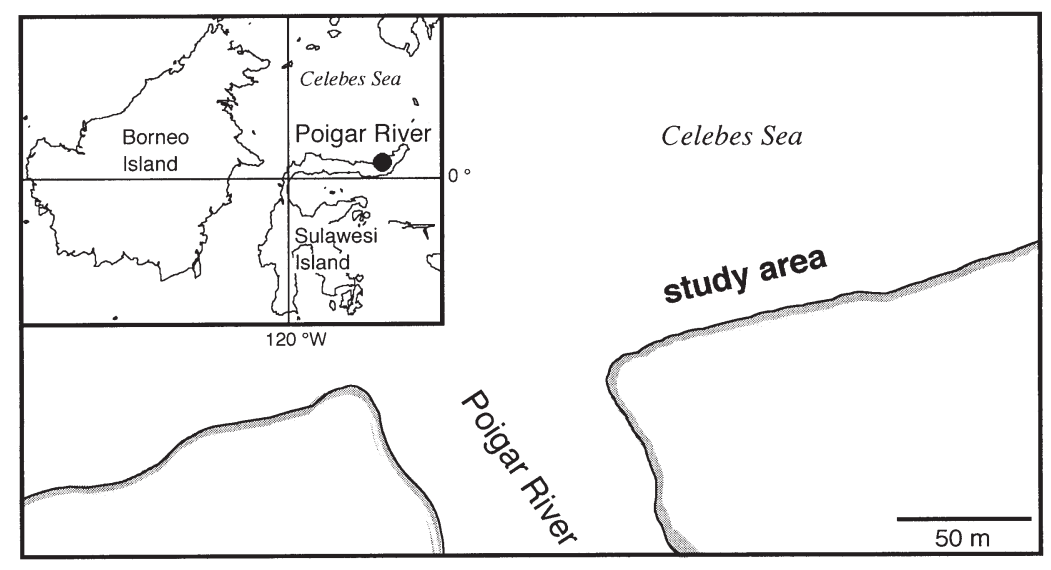

Fig. 1. The location of study area in the estuary of the Poigar River, north Sulawesi Island, Indonesia 
with scoop nets and a larger surface net (mouth $2.2 \mathrm{~m}$ ), as well as visual observations, indicated that glass eels were most abundant close to shore where we conducted our systematic sampling. This fishing effort was carried out throughout the year from 1997 to 1999, with 37 sampling dates at new moon, 36 at full moon, and additional sampling dates at the waxing and waning moons during 10 of the months. The glass eels were fixed in $10 \%$ formalin just after capture and the specimens were counted.

During the 37 sampling dates at new moon, all specimens were examined when the catch was 500 individuals or less, but when over 500 were collected, 500 to 2000 specimens were randomly selected and morphologically examined. A total of 10074 specimens were examined, and total length, pre-dorsal length, anodorsal length, and pre-anal length were measured to the nearest $0.1 \mathrm{~mm}$. Pigmentation stage was determined according Bertin (1956). The samples then were stained with alizarin-red solution, and sections of vertebrae (total vertebrae, pre-dorsal vertebrae, preanal vertebrae, and ano-dorsal vertebrae) were counted according to Tabeta et al. (1976), Tzeng \& Tabeta (1983), and Watanabe (2001).

The study by Arai et al. (1999a) determined that 3 species of angullid eels (Anguilla bicolor pacifica, A. celebesensis, and A. marmorata) recruited to the Poigar River estuary in 1997 based on the genetic (PCR-restriction length polymorphism analysis) and morphological (the ano-dorsal length as a percentage of total length) analyses. However, the character of ano-dorsal length as a percentage of total length overlapped between the 2 long-finned eels (A. celebesensis and $A$. marmorata). Therefore, we identified species on the basis of the ranges of number of ano-dorsal vertebrae (ADV) reported by Tabeta et al. (1976), Tzeng \& Tabeta (1983), and Watanabe (2001). Using that character, we determined the species composition of all the specimens examined each month during the 3 years of the study and used the relative proportion of each species to estimate the overall species composition of the glass eels recruiting to the Poigar River estuary from 1997 to 1999.

The environmental factors of lunar phase, light intensity, and tidal cycle were investigated in relation to the abundance of glass eels. Sampling took place 10 times during complete lunar cycles in March, July, October, and November in 1997, in March, August, and September in 1998, and in February, June, and October in 1999 to examine the effect of the lunar cycle on glass eel abundance. To examine the effect of light intensity, light intensity was measured throughout the hourly sampling periods in 1997 and the data grouped by each lunar phase (13 times new moon, 4 times waxing moon, 12 times full moon, and 4 times waning moon) for comparison. Light intensity was measured just before and after each sampling event using a lux meter (illuminance meter IM-3 Topcon Corp., Tokyo, Japan), then the average of the 2 light intensity measurements was used in the analysis. Tidal data were grouped hourly according to the date of catch in each lunar phase and were used for comparison with the number of glass eels collected. The tidal levels were based on the hourly tide tables issued by the Indonesian Navy for the north Sulawesi Island region in 1997. Hourly catch variation in relation to tide levels was tested using non-parametric tests (Zar 1999) for the new moon samples when glass eels were most abundant.

\section{RESULTS}

\section{Species composition}

A total of 32836 glass eels were collected from 1997 to 1999 in the Poigar River estuary, and 10074 specimens from the new moon samples were morphologically analyzed for species identification. Based on the ranges of number of ADV (Tabeta 1976, Tzeng \& Tabeta 1983, Watanabe 2001), 3 species of anguillid glass eels were present (Fig. 2). They were identified as Anguilla bicolor pacifica ( -2 to $3 \mathrm{ADV}), A$. celebesensis (6 to $12 \mathrm{ADV}$ ), and A. marmorata (14 to $18 \mathrm{ADV}$ ).

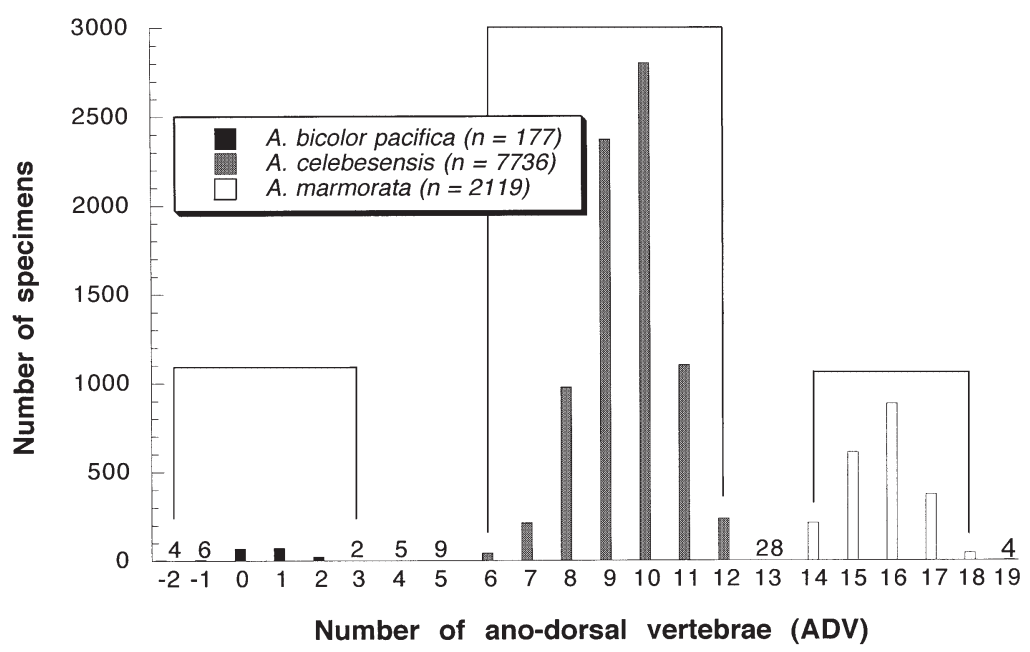

Fig. 2. Anguilla bicolor pacifica, A. celebesensis, and A. marmorata. Frequency distribution of the number of ano-dorsal vertebrae (ADV) collected in the Poigar River estuary 


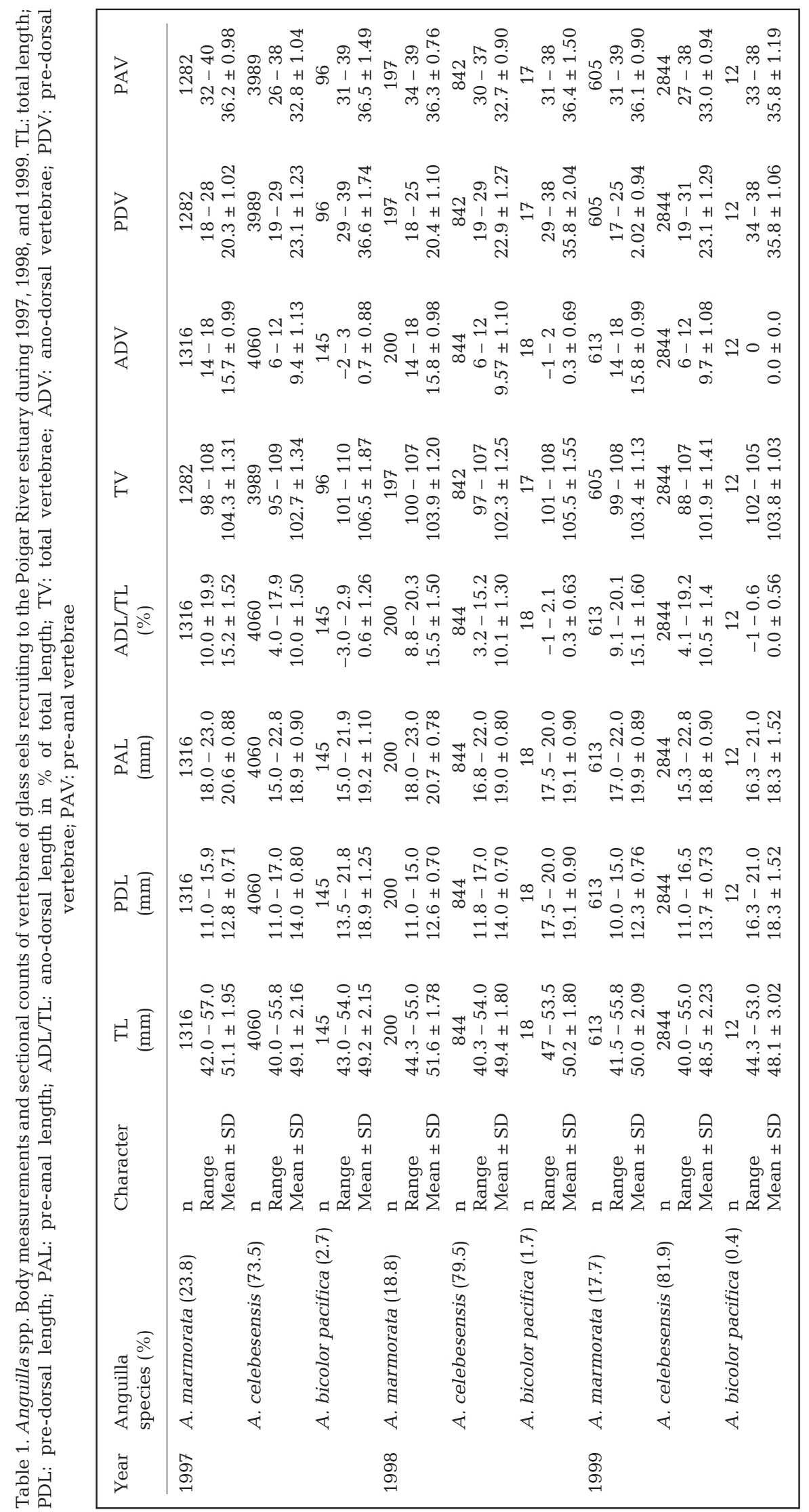

The character of 13 ADV apparent in this study was excluded to avoid misidentification since it would have caused an overlap between $A$. celebesensis and A. marmorata (Watanabe 2001). Furthermore, new numbers of $\operatorname{ADV}(4,5$, and 19) were found that are between the published ranges for A. bicolor pacifica and A. celebesensis. There was substantial overlap between species in terms of other characters such as total length, pre-anal length, pre-dorsal length, and ano-dorsal length as a percentage of total length, as well as total vertebrae, pre-dorsal vertebrae, and pre-anal vertebrae (Table 1). The mean and average of each character was similar between years for each species, suggesting that there were only these 3 species recruiting to the Poigar River. A. celebesensis was the most dominant species collected, comprising 73.5, 79.5, and $81.9 \%$ of the glass eels that were identified in 1997, 1998, and 1999, respectively. A. marmorata was the second most abundant species each year $(23.8,18.8,17.7 \%)$ and only a few $A$. bicolor pacifica were present $(2.7,1.7$, and $0.3 \%)$. All specimens had poorly developed pigmentation on the caudal, skull, and rostral regions of the body and were classified as stage VA or VB (Table 2). During the 3 years of investigation, A. marmorata and $A$. bicolor pacifica were predominantly at the earlier stage VA with 90.5 and $87.1 \%$, respectively, of the specimens being at this stage. In contrast, the proportions of A. celebesensis specimens at each stage of pigmentation were similar between stage VA $(47.1 \%$ of occurrence) and stage VB (52.9\% of occurrence). 
Table 2. Anguilla spp. Occurrence of each pigmentation stage of glass eels Crecruiting in the Poigar River estuary during 1997, 1998, and 1999

\begin{tabular}{|clccc|}
\hline \multirow{2}{*}{ Year } & Anguilla spp. & No. of & \multicolumn{2}{c|}{ Pigmentation stage (\%) } \\
& & VA & VB \\
\hline \multirow{1}{*}{1997} & A. marmorata & 1290 & 85.6 & 15.4 \\
& A. celebesensis & 3984 & 50.0 & 50.0 \\
& A. bicolor pacifica & 122 & 91.8 & 8.2 \\
& A. marmorata & 200 & 89.6 & 10.4 \\
& A. celebesensis & 844 & 41.8 & 58.2 \\
& A. bicolor pacifica & 18 & 94.4 & 5.6 \\
& A. marmorata & 613 & 90.9 & 9.1 \\
& A. celebesensis & 2844 & 49.3 & 50.7 \\
& A. bicolor pacifica & 12 & 75.0 & 25.0 \\
\hline
\end{tabular}

\section{Seasonal occurrence}

The 32560 specimens collected in the 37 samples at new moon were separated into 21924 specimens from 1997, 1371 from 1998 and 9265 from 1999 (Fig. 3). Glass eels of at least 1 species were collected in the Poigar River estuary throughout the year in 1997, 1998, and 1999 (except in May 1999). The largest catches of glass eels were in June 1997 and 1998, and in September in 1999, with the smallest catches obtained in December 1997, January 1998, and May 1999 (Fig. 3).

The species composition during new moon of each month of 1997, 1998, and 1999 varied considerably among species and years (Fig. 4). All 3 species were present in at least 4 months of each year. Anguilla bicolor pacifica appeared almost throughout the year in 1997 , except in November, with a peak in June. At least 1 A. bicolor pacifica glass eel was identified each month in 1998 except in April, May, July, and August, with a peak in January. In 1999, this species was collected only in January, February, June, and July with fewer than 5 specimens collected each month. In 1997, A. celebesensis recruited to the mouth of Poigar River throughout the year with a peak in June and the smallest catch in December. In 1998, this species recruited almost throughout the year except in January, February, and April while the peak was in June. In 1999, A. celebesensis appeared almost throughout the year except in May, with a peak in September. A. marmorata was present throughout the year in 1997, except in December, and reached a peak in June. In 1998, this species was not found in January and reached a peak in June. No specimens of A. marmorata were collected in May 1999, but the greatest number was collected in June.

\section{Environmental factors}

Glass eels swimming close to shore near the mouth of the Poigar River were collected only at night during various stages of the tidal cycle and were much more abundant at the new moon phase. There were 3075 individuals collected during the new moon samples obtained in the 10 months (from 1997 to 1999) used for comparison with the other 3 lunar phases (Fig. 5). In contrast, only 183 individuals were collected at waxing moon, 3 at full moon, and 90 at waning moon. During the $24 \mathrm{~h}$ sampling periods in 1997, glass eels were collected only at night from 18:00 to 05:00 h when light intensity ranged from 0 to 1.86 lux. (Fig. 6). No glass eels were collected 

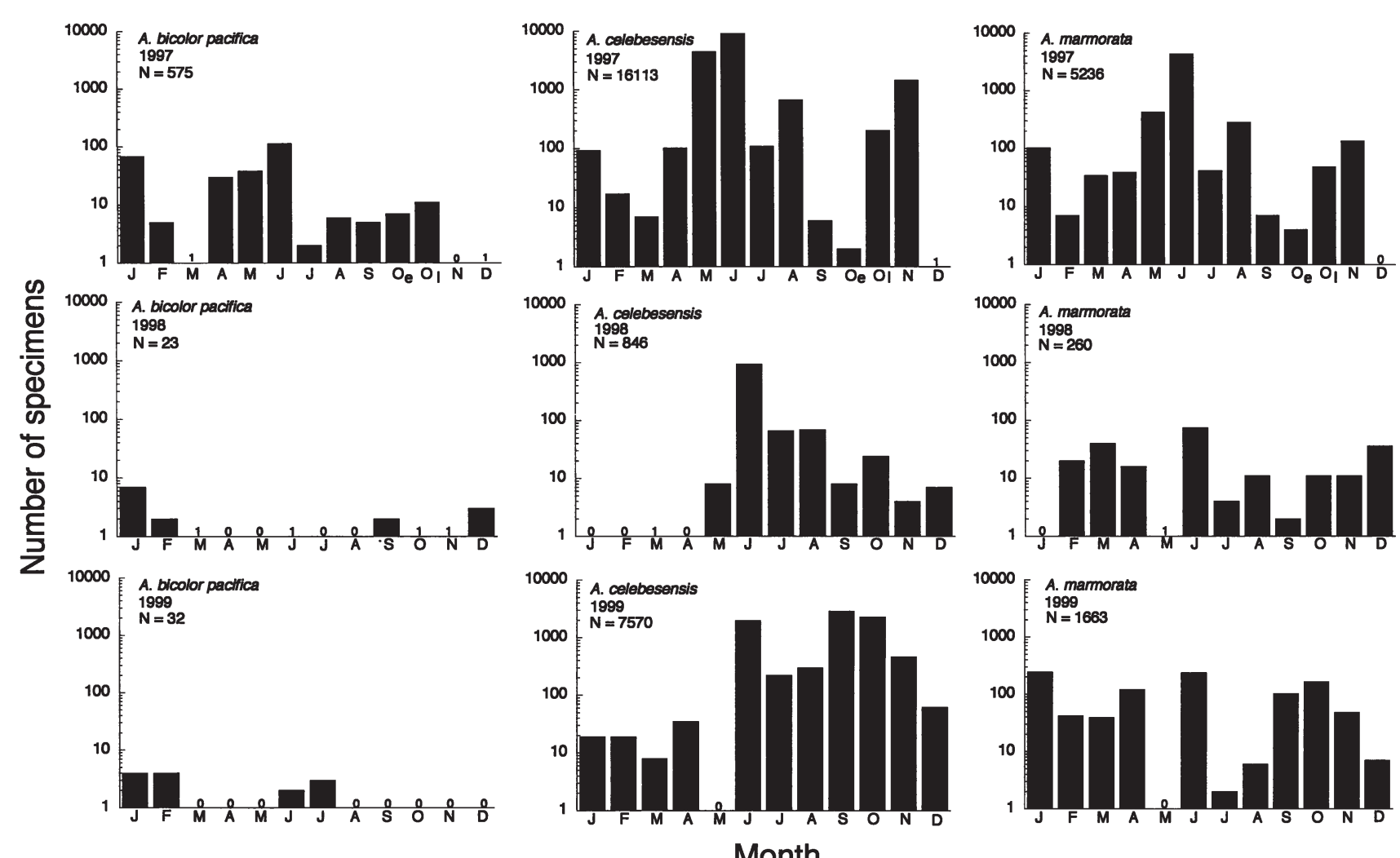

Fig. 4. Monthly abundance of glass eels of each species collected at new moon in the Poigar River Estuary from 1997 to 1999 (for October 1997 samples: e = early, l = late)

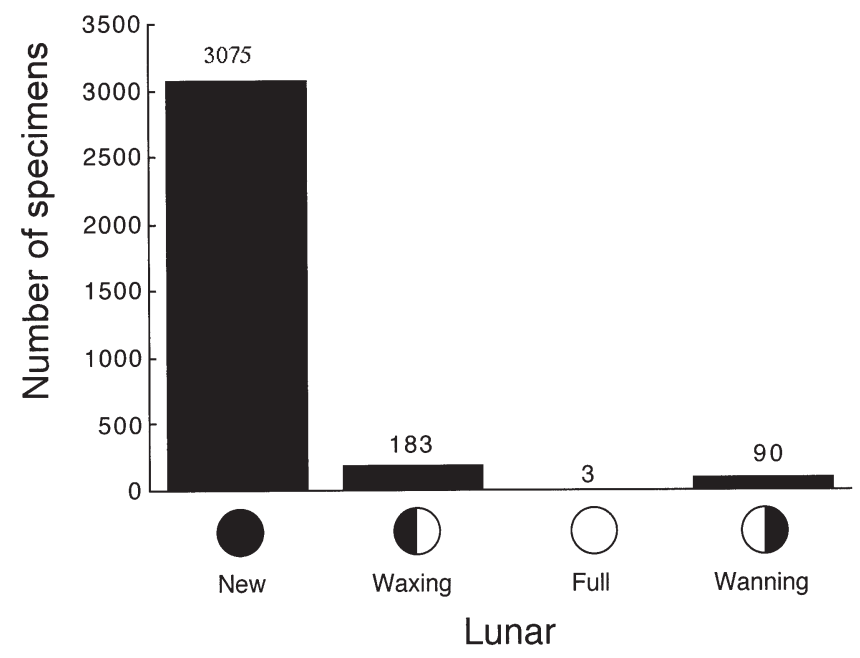

Fig. 5. Total number of glass eels of all 3 species collected in the Poigar River estuary at each lunar phase during 10 lunar cycles from 1997 to 1999

during daytime when the light intensity was high (500 to 150000 lux) during any of the lunar phases. Glass eels were collected at night during both ebb and flood tides at each phase of the moon, except for full moon (Fig. 6). At new moon when there were many more glass eels than during the other moon phases, a greater number of glass eels was caught during flood tide (19451 specimens) than during ebb tide (2289 specimens) (Wilcoxon test, $\mathrm{p}<0.05$ ). The majority of glass eels were also caught during flood tide at the waning moon, but most were caught during ebb tide at waxing moon and only 1 glass eel was caught at full moon.

\section{DISCUSSION}

\section{Species composition}

During the present study it was found that Anguilla celebesensis was consistently the most abundant species of anguillid glass eel that recruited to the mouth of the Poigar River, followed by A. marmorata and, to a much lesser extent, A. bicolor pacifica, but no other species of anguillid eels were identified. A preliminary study on the species diversity of anguillid eels from Sulawesi Island by Castle \& Williamson (1974) found the presence of a long-finned species of anguillid eel with plain body coloration in rivers on the island, which they identified as A. borneensis. However, as was the case for the 10074 specimens examined in the present study, the recent study by Arai et al. (1999a) on 

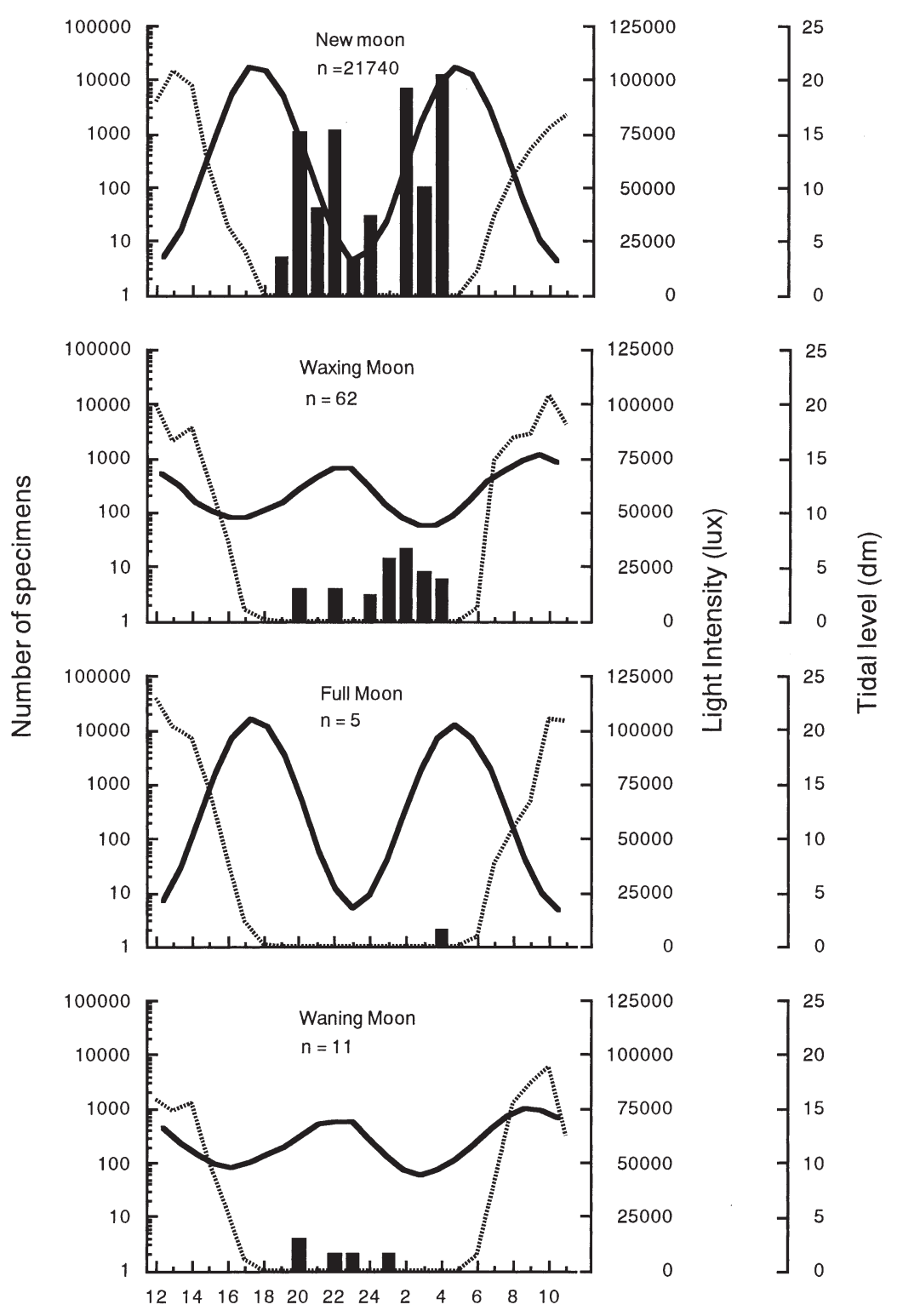

Hour

Fig. 6. Number of glass eels (histogram) collected in the Poigar River estuary in 1997 in relation to light intensity (dotted line) and tidal cycle (solid line)

the species composition of tropical eels recruiting to the Poigar River in 1997 did not find any specimens of A. borneensis among the 272 specimens used for genetic and morphological identification. All of their specimens were identified as A. celebesensis, A. marmorata, and $A$. bicolor pacifica based on mitochondrial DNA analysis and external morphological analysis (ano-dorsal length as a percentage of total length). Watanabe (2001) described the ranges of ADV of $A$. bicolor ( -3 to 3$)$, A. celebesensis (8 to 13 ), and $A$. marmorata (12 to 18 ) based on genetic and morphological studies of adult specimens of freshwater eels.

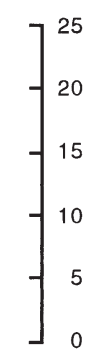

$-f^{25} \begin{gathered}20 \\ 15 \\ 10 \\ 0\end{gathered}$

In the present 3-year study of the species composition of glass eels at the Poigar River using external and internal morphological analysis of the quantitative catch samples, the same 3 species of Anguilla were identified as in the genetic analysis of Arai et al. (1999a). There was a large range in overlap of all the characters of body measurement and sectional counts of vertebrae, except for the number of ADV, for which there was a small overlap between the 2 long-finned eels. This indicates, morphologically, that the number of ADV is the most useful character for distinguishing the species of anguillid eels in tropical areas. The range of number of ADV in A. bicolor pacifica (-2 to 3), A. celebesensis (6 to 12), and A. marmorata (14 to 18 ) found in this study is wider than that found by Tabeta (1976) and Tzeng \& Tabeta (1983). However, it was the same as the ranges found by Watanabe (2001), except for the small overlap in number of ADV (12 and 13) between $A$. celebesensis and A. marmorata. In our study, we included the specimens with 6,7 , and $12 \mathrm{ADV}$ into the character of $A$. celebesensis and not A. marmorata as described by Watanabe (2001), on the basis of the normal frequency distributions of ADV on that species found in this study. In the present study, we also found new characters of number of ADV $(4,5$, and 19) between the ranges of A. bicolor pacifica and A. celebesensis. It would be reasonable to say that the new characters may belong to the ranges of $A$. bicolor pacifica or A. celebesensis if the number of specimens were more representative. Comparisons using both genetic and morphological analyses are needed to clarify the species identifications in these ranges of overlap of the ADV character. Differences in location of collection of specimens, the different life history stages of specimens, and smaller sample size are possible reasons for the variation in reported ranges. Regardless, it appears that only the 3 species A. bicolor pacifica, A. celebesensis, and A. marmorata have been found in the Poigar River in this study as well as in the studies by Arai et al. (1999a) and Watanabe (2001), in which molecular analysis was used. 
All specimens examined during the present study were in the early glass eel pigmentation stages VA or $\mathrm{VB}$, indicating that they probably recruit to the Poigar River estuary relatively soon after metamorphosis. However, the proportion of individuals with the later stage of pigmentation VB was higher in A. celebesensis than in A. marmorata and A. bicolor pacifica. Jellyman (1977) observed a seasonal progression in pigmentation stage in glass eels recruiting to New Zealand and suggested that the late season arrivals probably have a substantially longer post-metamorphic period in the ocean (oceanic glass eel stage) than earlier arrivals. However, this does not appear to explain the observations of the present study. There may be developmental or behavioral differences among these species that results in their slight difference in pigmentation.

\section{Seasonal occurrence}

The temporal patterns of glass eel catches near the mouth of the Poigar River differed among species and years, suggesting that there is considerable interannual variation in the recruitment patterns of glass eels in the region. Catches of Anguilla celebesensis and A. marmorata peaked in June in 1997 and 1998, but in 1999 the catch of $A$. celebesensis was relatively high in June and peaked later in September and October. The greatest catches of A. marmorata in 1999 were in January and June. In contrast, it was difficult to determine the time of peak abundance of $A$. bicolor pacifica because very few specimens were collected and no specimens were collected during several months in 1997, 1998, and 1999. Additional collections in other years will be needed to determine whether there is a seasonal trend to the recruitment of $A$. bicolor pacifica and whether the peak catches in June or later in the year are consistent patterns of the other 2 species.

Although at least a few glass eels of the tropical species studied here appear to recruit year round, temperate anguillid species appear to have much shorter seasonal ranges in recruitment period. In the northern hemisphere, Anguilla japonica glass eels recruit to the east coast of Japan from October to May (Matsui 1952), but they recruit to the west coast of southern Japan later, from January to June (Kawakami et al. 1999). For the Atlantic temperate eels, the peak in recruitment of A. rostrata has been reported to be in April and May (Haro \& Krueger 1988), and the recruitment season of A. anguilla was from late November to early July, with the peak of upstream migration into freshwater in February and May (Gandolfi et al. 1984). In the southern hemisphere, on several streams in eastern Tasmania, the glass eels of $A$. australis were collected at the first riffle during all seasons of the year except mid-summer, with a peak in October, and during late summer and autumn for the more tropical $A$. reinhardtii glass eels, with a peak in April (Sloane 1984). Jellyman (1977) found that the invasion by both New Zealand species into the Makara Stream commenced in July, while that of the long-finned eel $A$. dieffenbachii was finished by November with peaks in August and September, and that of the short-finned eel A. australis schmidtii was finished by December with peaks in September and October. This was similar to the seasonal migration of both species in the Waikato River, New Zealand, where the main migratory period extended from August to October (Jellyman 1979). Therefore, it appears that tropical glass eels may tend to recruit throughout the year while most temperate species appear to recruit during about half of the year or less. The evolution of a narrower range in spawning and recruitment times of temperate eels may be explained by the much greater seasonal differences in hydrographic conditions in the ocean and in environmental conditions such as temperature and productivity in the temperate freshwater habitats that glass eels are entering.

Further support for the difference in life history patterns between temperate and tropical eels comes from studies of the otolith microstructure of glass eels of Anguilla celebesensis, A. marmorata, and A. bicolor pacifica, which suggest that these species spawn throughout the year (Arai et al. 2001). Otolith Sr:Ca ratio analysis using an X-ray electron microprobe also has suggested that metamorphosis from leptocephali into glass eel probably begins 3 to 5 mo after hatching, and recruitment to the estuary occurs at ages of 4 to 6 mo (Arai et al. 1999d,e, 2001). Furthermore, the otolith early life history parameters such as age at metamorphosis, duration of metamorphosis, age at recruitment, and duration of the oceanic glass eel stage were found to be almost constant in each species throughout the year (Arai 2000, Arai et al. 2001). Therefore, the inshore migration period in tropical species appears to extend throughout the year due to year-round spawning and larval transport in relatively constant environmental conditions, in contrast to the temperate species, which have a more limited spawning season.

Recent studies on the otolith microstructure of glass eels collected at the mouth of the Poigar River found that the ages of the Anguilla celebesensis, A. marmorata, and $A$. bicolor pacifica specimens ranged from 104 to 118,144 to 182 , and 158 to 201 d respectively (Arai et al. 1999d,e, 2001). This indicated that $A$. celebesensis was the youngest among those 3 species and suggested that the spawning area of A. celebesen- 
sis might be closer to the Poigar River than those of the other species. Jespersen (1942) suggested that the spawning ground of tropical eels, including A. celebesensis and $A$. marmorata distributed around north Sulawesi Island, is located in the Celebes and Molluca Seas close to their distribution area. If this idea is correct, it might be one possible reason why A. celebesensis and $A$. marmorata appear to be the dominant species recruiting to the mouth of Poigar River. The spawning ground of $A$. bicolor pacifica may be farther away or they may have smaller population sizes in the region than the other species. Research on the downstream spawning migration of the adults and on the distribution of the leptocephali of these species in the region is required to determine the reason for the life history patterns observed in their glass eels.

\section{Timing of inshore migration}

Light intensity appears to have a strong effect on the inshore migration mechanisms of glass eels entering the mouth of the Poigar River as has been observed in previous studies with other species. Usually fish migrate upstream mainly during twilight and dark periods (Jonsson 1991), and Deelder (1952) found that Anguilla anguilla glass eels migrated during darkness. They started to ascend into freshwater at the beginning of sunset, with abundance gradually increasing during the night up to a peak around midnight and then rapidly decreasing just before sunrise. The ascent of A. anguilla elvers into the Arno River (Italy) was observed in the evening hours with the greatest abundance in the hours immediately following sunset (Gandolfi et al. 1984). A. japonica elvers migrated into and were active in an estuary along the northern coast of Taiwan at night (Tzeng 1985). In contrast, Jellyman (1979) found that A. australis and A. dieffenbachii glass eels migrated during both day and night, and he suggested that light was not influencing either the periodicity or the magnitude of upstream migration of both species in the Waikato River, New Zealand. However, temperate glass eels have been reported to begin their inshore migration when the light intensity gradually decreased from 120 to 9 lux (Tesch 1977), but no glass eels were collected in the Poigar River estuary when the light intensity was in the same range. This suggests that although some species may move during the day or in low light, both tropical and temperate glass eels may be negatively phototaxic. Further studies on the light tolerance of tropical glass eels may help determine the influence of low light levels on their inshore migration.

At night, the greatest number of glass eels were collected during this study at new moon and the fewest at full moon, suggesting that the lunar phase has a strong effect on inshore migration mechanism of glass eels at the mouth of the Poigar River. A simillar pattern was observed by Gollub (cited in Tesch 1977) who found that during the 3-month period of investigation, maximum catches of Anguilla anguilla elvers were recorded in the waning moon or at the new moon. Tzeng (1985) reported that catches of $A$. japonica elvers in Taiwan reached peak abundance only once a month around the time of new moon. In contrast, Jellyman (1979) found that upstream migration of $A$. australis and A. dieffenbachi occurred at full moon or new moon and rose to a peak generally 4 days later, which appeared to be related to the increased amplitude of spring tides. These observations suggest that the lunar cycle may be a major factor affecting the inshore migration of the glass eels of many different species of anguillid eels.

Although glass eels were collected near shore close to the mouth of the Poigar River to some degree during both ebb (20:00 to 22:00 h) and flood (02:00 to 04:00 h) tides, during of new moon there were more glass eels during flood tide than ebb tide. Previous studies have found that the glass eels of temperate anguillid species tend to synchronize their upstream migration with flood tides. During new moon, Kuhl (cited in Tesch 1977) found that glass eel migration began at 21:00 $\mathrm{h}$ when the flood tide began to flow, reached its maximum at high water, and was over 1 or $2 \mathrm{~h}$ later when they disappeared from the surface waters. Upstream migration of glass eels of Anguilla australis and A. dieffenbachii is thought to occur preferentially at flood tide, although migrations are frequently recorded over both tidal phases (Jellyman 1979). Other studies have found that glass eels use the behavioral pattern of semidiurnal vertical migration called 'selective tidal stream transport', in which individuals enter the water column during flood tide and remain on the bottom during ebb tide, resulting in passive upstream transport. This behavior has been observed in A. anguilla elvers (Creutzberg 1958), A. rostrata glass eels (McCleave \& Kleckner 1982, McCleave \& Wippelhauser 1987, Wippelhauser \& McCleave 1988), and elvers of $A$. australis and A. diffenbachi in New Zealand (Jellyman 1977). Selective tidal stream transport appears to allow glass eels to migrate quickly through areas with strong tidal flow with minimum energy expenditure. In contrast, Gandolfi et al. (1984) found that the ascent of $A$. anguilla elvers near shore at the mouth of the Arno River was not statistically different during flood and ebb tides. The variable timing of catches in relation to the tidal cycle in the present study may be due in part to the location of sampling, which was not within the river where tidal flows would be the greatest, but was near shore outside the river mouth were flows would be expected to be less influenced by tidal flow. 
In conclusion, the findings of this study confirm that there may only be 3 species of tropical eels that recruit to the Poigar River in Indonesia, with Anguilla celebesensis being the most abundant species, and that all 3 species may be present to some degree at any time of year. Studies in the laboratory or with different types of sampling gear fished in the Poigar River itself will be helpful to further examine the influence of environmental factors such as light intensity, tidal cycle, salinity, and temperature on the inshore migration of tropical glass eels.

Acknowledgements. We are grateful to the students of Aquatic Resources Management Laboratory, Sam Ratulangi University, Indonesia, for their assistance during the field study, and thank Ms. M. Oya for her great support in many aspects of the study. This work was supported in part by Grants-in-Aid No. 07306022, 07556046, 08041139, 08456094, and 11691177 from the Ministry of Education, Science, Sport and Culture, Japan; Research for the Future Program No. JSPS-RFTF 97L00901 from the Japan Society for the Promotion of Science; Eel Research Foundation from Nobori-kai; and Research Foundation from Touwa Shokuhin Shinkoukai. Partial support was also given in the form of a Research Fellowship of the Japan Society for the Promotion of Science for Young Scientists to T.A. and a Research Student Scholarship from the Ministry of Education, Science, Sport, and Culture of Japan to H.Y.S.

\section{LITERATURE CITED}

Aoyama J, Nishida, M, Tsukamoto K (2001) Molecular phylogeny and evolution of the freshwater eel, genus Anguilla. Mol Phylogen Evol 20:450-459

Arai T (2000) Ecological study on the inshore migration of the eels, Anguilla spp. in Sulawesi Island. Ph.D thesis, The University of Tokyo

Arai T, Otake T, Tsukamoto K (1997) Drastic changes in otolith microstructure and microchemistry accompanying the onset of metamorphosis in the Japanese eel Anguilla japonica. Mar Ecol Prog Ser 161:17-22

Arai T, Aoyama J, Limbong D, Tsukamoto K (1999a) Species composition and inshore migration of the tropical eels Anguilla spp. recruiting to the estuary of the Poigar River, Sulawesi Island. Mar Ecol Prog Ser 188:299-303

Arai T, Otake T, Jellyman DJ, Tsukamoto K (1999b) Differences in the early life history of the Australasian shortfinned eel, Anguilla australis from Australia and New Zealand, as revealed by otolith microstructure and microchemistry. Mar Biol 135:381-389

Arai T, Limbong D, Aoyama J, Otake T, Tsukamoto K (1999c) Diversity of tropical anguillid eels: early life history and migration. Proc Ninth JSPS Joint Semin Mar Fish Sci 215-228

Arai T, Limbong D, Otake T, Tsukamoto K (1999d) Metamorphosis and inshore migration of tropical eels Anguilla spp. in the Indo-Pacific. Mar Ecol Prog Ser 182:283-293

Arai T, Otake T, Limbong D, Tsukamoto K (1999e) Early life history and recruitment of the tropical eel, Anguilla bicolor pacifica, as revealed by otolith microstructure and microchemistry. Mar Biol 133:319-326
Arai T, Otake T, Tsukamoto K (2000) Timing of metamorphosis and larval segregation of the Atlantic eels Anguilla rostrata and $A$. anguilla, as revealed by otolith microstructure and microchemistry. Mar Biol 137:39-45

Arai T, Limbong D, Otake T, Tsukamoto K (2001) Recruitment mechanisms of tropical eels Anguilla spp. and implications for the evolution of oceanic migration in the genus Anguilla. Mar Ecol Prog Ser 216:253-264

Bastrop R, Strehlow B, Jurss K, Sturmbauer C (2000) A new molecular phylogenetic hypothesis for the evolution of freshwater eels. Mol Phylogen Evo1 4:250-258

Bertin L (1956) Eels: a biological study. Cleaver-Hume Press, London

Castle PHJ, Williamson GR (1974) On the validity of the freshwater eel species Anguilla ancestralis Ege from Celebes. Copeia 2:569-570

Cheng PW, Tzeng WN (1996) Timing of metamorphosis and estuarine arrival across the dispersal range of the Japanese eel Anguilla japonica. Mar Ecol Prog Ser 131:87-96

Creutzberg F (1958) Use of tidal streams by migrating elvers (Anguilla vulgaris Turt). Nature 181:857-858

Deelder CL (1952) On the migration of the elver (Anguilla vulgaris Turt.) at sea. J Cons Int Explor Mer 20:187-218

Ege V (1939) A revision of the genus Anguilla Shaw: a systematic, phylogenetic and geographical study. Dana Rep 16:1-256

Gandolfi G, Pesaro M, Tongiorgi P (1984) Environmental factors affecting the ascent of elver, Anguilla anguilla (L) into the Arno River. Oebalia 5:17-35

Gascuel D (1986) Flow-carried swimming migration of the glass eel (Anguilla anguilla) in the tidal area of a small estuary on the French Atlantic coast. Helgol Meeresunters 40:321-326

Haro AJ, Krueger WH (1988) Pigmentation, size, and migration of elvers Anguilla rostrata (Lesueur) in a coastal Rhode Island stream. Can J Zool 66:528:2533

Jellyman DJ (1977) Invasion of a New Zealand freshwater stream by glass eels of two Anguilla spp. N Z J Mar Freshw Res 11:193-209

Jellyman DJ (1979) Upstream migration of glass-eels (Anguilla spp.) in the Waikato River. N Z J Mar Freshw Res 13:13-22

Jellyman DJ, Chisnall BL, Bonnett ML, Sykes JRE (1999) Seasonal arrival pattern of juvenile freshwater eels (Anguilla spp.) in New Zealand. N Z J Mar Freshw Res 33:249-261

Jespersen P (1942) Indo-Pacific leptocephali of the genus Anguilla. Dana Rep 22:1-128

Jonsson N (1991) Influence of water flow, water temperature and light on fish migration in rivers. Nord J Freshwat Res 66:20-35

Kawakami Y, Mochioka N, Nakazono A (1999) Immigration patterns of glass-eels Anguilla japonica entering river in northern Kyushu Japan. Bull Mar Sci 64:315-327

Lecomte-Finiger R (1992) Growth history and age at recruitment of European glass eels (Anguilla anguilla) as revealed by otolith microstructure. Mar Biol 114:205-210

Martin MH (1995) The effects of temperature, river flow, and tidal cycles on the onset of glass eel and elver migration into freshwater in the American eel. J Fish Biol 46: 891-902

Marui M, Arai T, Miller MJ, Jellyman DJ, Tsukamoto K (2001) Comparison of early life history between New Zealand temperate eels and Pacific tropical eels revealed by otolith microstructure and microchemistry. Mar Ecol Prog Ser 213:273-284

Matsui I (1952) Study on the morphology, ecology and pond 
culture of the Japanese eel (Anguilla japonica Temminck \& Schlegel). J Shimonoseki Coll Fish 2:1-245

McCleave JD, Kleckner RC (1982) Selective tidal stream transport in the estuarine migration of glass eels of the American eel (Anguilla rostrata). J Cons Int Explor Mer 40:262-271

McCleave JD, Wippelhauser GS (1987) Behavioural aspects of selective tidal stream transport in juvenile American eels. Am Fish Soc Symp 1:138-150

Schmidt J (1922) The breeding places of the eel. Philos Trans R Soc Lond B 211:179-208

Sloane RD (1984) Distribution, abundance, growth and food of freshwater eel (Anguilla spp) in the Dauglass River, Tasmania. Aust J Mar Freshw Res 35:325-339

Sorensen PW (1986) Origins of the freshwater attractant(s) of migrating elvers of the American eel Anguilla rostrata. Environ Biol Fish 17:185-200

Sorensen PW, Bianchini ML (1986) Environmental correlates of the freshwater migration of elvers of the American eel in a Rhode Island brook. Trans Am Fish Soc 115:258:268

Tabeta O, Takai T, Matsui I (1976) The sectional counts of vertebrae in the anguillid elvers. Jap J Ichthyol 22:195-200

Tesch FW (1977) The eel: biology and management of anguillid eels. Chapman \& Hall/John Wiley \& Sons, New York

Todd PR (1981) Timing and periodicity of migrating New Zealand freshwater eel (Anguilla spp.). N Z J Freshw Res 1:227-235

Tongiorgi P, Tosi L, Balsamo M (1986) Thermal preferences in upstream migrating glass-eels of Anguilla anguilla. J Fish Biol 28:501-510

Editorial responsibility: Otto Kinne (Editor), Oldendorf/Luhe, Germany
Tsukamoto K (1990) Recruitment mechanism of the eel, Anguilla japonica, to the Japanese coast. J Fish Biol 36: 659-671

Tsukamoto K (1992) Discovery of the spawning area for the Japanese eel. Nature 356:789-791

Tsukamoto K, Aoyama J (1998) Evolution of freshwater eels of the genus Anguilla: a probable scenario. Environ Biol Fish 52:139-148

Tzeng WN (1985) Immigration timing and activity rhythms of the eel, Anguilla japonica elvers in the estuary of northern Taiwan, with emphasis on environmental influences. Bull Jap Soc Fish Oceanogr 47:11-28

Tzeng WN, Tabeta O (1983) First record of the short-finned eel Anguilla bicolor pacifica elvers from Taiwan. Bull Jap Soc Sci Fish 49:27-32

Wang $\mathrm{CH}$, Tzeng WN (1998) Interpretation of geographic variation in size of American eel Anguilla rostrata elvers on the Atlantic coast of North America using their life history and otolith ageing. Mar Ecol Prog Ser 168:35-43

Watanabe S (2001) Taxonomic study on the freshwater eels, genus Anguilla Schrank. Ph.D thesis, The University of Tokyo

Wippelhauser GS, McCleave JD (1987) Precision of behavior of migrating juvenile American eels (Anguilla rostrata) utilizing selective tidal stream transport. J Cons Int Explor Mer 44:80-89

Wippelhauser GS, McCleave JD (1988) Rhythmic activity of migrating juvenile American eels Anguilla rostrata. J Mar Biol Assoc UK 68:81-91

Zar JH (1999) Biostatistical analysis, 4th edn. Prentice Hall, Upper Saddle Rriver, NJ

Submitted: February 19, 2001; Accepted: May 25, 2001

Proofs received from author(s): September 20, 2001 